\title{
THE IMPACT OF THE FARMER FIELD SCHOOL APPROACH ON SMALL-SCALE VEGETABLE PRODUCERS' KNOWLEDGE AND PRODUCTION IN ALICE, EASTERN CAPE, SOUTH AFRICA
}

\author{
Apleni, A. ${ }^{1}$, Aliber, M. ${ }^{2}$, Zhou, L. ${ }^{3}$ and Zantsi, S. ${ }^{4}$ \\ Correspondence author: A. Apleni. Email: apleniasanda@gmail.com
}

\begin{abstract}
This paper investigates the impact of the farmer field school approach on the knowledge and production of small-scale vegetable producers, namely home gardeners. Farmer field schools were developed in the 1980s by the Food and Agriculture Organisation as a form of adult education in agriculture. It is a group-based approach in which a facilitator meets with producers on a regular basis and sets in motion a process by which producers 'learn how to learn'. It remains an open question whether the farmer field school approach could be a solution to South Africa's abiding problem of weak agricultural extension. In early 2015, the University of Fort Hare and the Nkonkobe Farmers' Association initiated a number of study groups in the Alice area of the Eastern Cape Province of South Africa, based largely on farmer field school principles. The research findings reported in this article are part of an effort to determine to what extent these study groups had the desired effect. After administering surveys to 118 study group members, before and after comparisons were drawn with regards to members' self-assessed knowledge and skills, and production levels of a number of garden vegetables. The findings revealed an impressive increase in self-assessed knowledge and skills, as well as in production, consumption and selling of vegetables. Based on these findings and given the current state of agricultural extension in South Africa, it can be recommended that expansion of the farmer field school approach takes place in other areas, while attempting to better understand the mechanisms underlying the improvements already observed.
\end{abstract}

Keywords: Agricultural extension, Farmer field schools, Small-scale farmers

\section{INTRODUCTION}

According to Statistics South Africa (StatsSA)'s Community Survey of 2016 (StatsSA, 2016), South Africa has more than two million households involved in agriculture. The vast majority of these are subsistence producers, and most live and farm in the rural areas (Pienaar \& Von Fintel, 2014). Small-scale agriculture remains a modest but important source of livelihood for many poor rural households (Aliber \& Hart, 2009), yet it is failing to provide a route out of poverty for the majority. While small-scale producers have numerous needs, it is commonly accepted that agricultural extension is an important one of these. For example, in the National Development Plan, the need and importance of agricultural advisory service is emphasised in

\footnotetext{
${ }^{1}$ Researcher, Agricultural \& Rural Development Research Institute (ARDRI), University of Fort Hare, Alice, South Africa; ORCiD number 0000-0003-1442-2733

${ }^{2}$ Director, Agricultural \& Rural Development Research Institute (ARDRI), University of Fort Hare, Alice, South Africa; ORCiD number 0000-0001-8739--0379

${ }^{3}$ Director, Risk \& Vulnerability Science Centre, University of Fort Hare, Alice, South Africa; ORCiD number 0000-0002-0344-4710

${ }^{4} \mathrm{PhD}$ Student, Department of Agricultural Economics, Stellenbosch University, Stellenbosch, South Africa, ORCiD number: 0000-0001-9787-3913
} 
realising the development of small-scale producers (National Planning Commission, 2011). However, it is also commonly accepted that South Africa's current extension services are not as strong and effective as they are expected to be (Koch \& Terblanche, 2013; Lukhalo, 2017; Worth, 2008). There are various theories as to what is lacking with government's extension services. In government's own view, much of the problem is too few extension officers, inadequate skills amongst extension officers, and inadequate co-ordination between government and private sector extension services. From another perspective, which government itself has indirectly acknowledged, is that one of the main problems is the extension methodology, which is dominantly a training and visit approach. This includes the Extension Recovery Programme launched in 2008/09 (Department of Agriculture, Forestry and Fisheries (DAFF), 2013), the Strategic Plan for Smallholder Support (DAFF, 2014), and the National Policy on Extension and Advisory Services (DAFF, 2014). However, there is no adequate evidence of success of these programmes in strengthening the extension service.

While there are various alternative extension approaches around the world, one that has gained much attention over the years is farmer field schools (FFS). The FFS approach began in Indonesia in the late 1980s, and is a group-based learning process whereby producers meet on a weekly basis at a site they provide, and are assisted by a facilitator who may or may not be a qualified extension officer (Pontius, Dilts \& Barttlet, 2002). The group-based, facilitated process is not the only distinguishing feature of FFS. Arguably the most essential element of the approach is that it prioritises the importance of producers learning for themselves and from one another through direct experience, as opposed to being passive recipients of information and technologies provided by others, such as extension officers (Duveskog, 2013). This does not preclude accessing external information and technologies; rather in principle, it means that producers will be more selective and effective users of such information and technologies (Duveskog, 2013). FFS have now expanded to many parts of sub-Saharan Africa (Friis-Hansen \& Duveskog, 2012).

In different parts of the continent, the FFS approach is effectively used to support small-scale producers. The FFS approach is gradually gaining attention amongst development actors as a community-based, non-formal education method that appears to meet both the technological and social needs of producers (Davis, 2006). The FFS approach has also been successfully applied in a wide range of contexts (Braun et al, 2006; Davis et al, 2010).

However, the literature on the impact of the FFS approach in South Africa is scarce, seemingly because the approach has been little tried in South Africa. It therefore remains an open question whether the FFS approach could work in South African conditions. In an attempt to address this question, the University of Fort Hare and the Nkonkobe Farmers' Association ${ }^{5}$ initiated six study groups near the town of Alice in the Eastern Cape Province of South Africa in 2015, which were based largely on FFS principles. Each study group met once a week for the first six months after establishment, dropping to twice per month thereafter. The purpose of the meetings was to enable group members to discuss challenges and share information with one another. Meetings can last from one to three hours, and often involve visiting one or two members' gardens in order to observe. From time to time, workshops and practical demonstrations are held with the groups by experts from the University of Fort Hare, Rhodes

\footnotetext{
${ }^{5}$ The Nkonkobe Farmers' Association has since become the Raymond Mhlaba Farmers' Association, which continues to work with the University of Fort Hare in support of study groups in the area, of which there are currently nine.
} 
University, Fort Cox Agricultural College, and Umtiza Farmers Coop. Each group is composed of 16-20 members and has a leader/chairperson whom they elected to manage the study group meetings.

This article reports on an analysis conducted of the study groups during the first two to three years of the study group initiative. The objective of this study was to assess the impact of the FFS approach, specifically on participation in the study groups and small-scale vegetable producers' knowledge and production levels.

\section{METHODOLOGY}

\subsection{Study area}

The study was carried out in Raymond Mhlaba Local Municipality, which is part of Amathole District Municipality in the Eastern Cape Province. Specifically, the focus was on four villages in Tyhume Valley known collectively as Gwali (encompassing five study groups), as well as on Golf Course, a low-cost housing settlement making up part of the town of Alice (one study group). According to Stats SA's population census in 2011, Gwali had a total population of 2801 residents, belonging to 752 households, while the population of Golf Course was 3157 in 1289 households (StatsSA, 2012).

\subsection{Approach, design and sample size}

The study involved two main research activities. The first activity involved participant observation, whereby the researcher sat in on the facilitated study groups facilitated in order to observe how participants behave and interact, paying particular attention to their attitudes towards learning and decision-making. A diary was used to record descriptive accounts of the study groups' activities and discussions. The second research activity involved the administration of surveys with study group members. The survey interviews used a semistructured questionnaire containing both closed and open-ended questions.

The questionnaire captured members' demographic information, their self-assessments with regards to their gardening skills and knowledge, and data regarding quantities of vegetables produced, consumed and sold. The section on skills and knowledge included a number of statements (e.g. 'I have a great deal of skill on how to tell how fertile the soil is') to which the respondent was asked to agree or disagree according to a 5-point Likert scale. Additional sections of the questionnaire included the nature and extent of support from government extension officers, and how members market their produce. However, these sections do not form part of the discussion of this paper as they were not relevant to the topic.

The surveys probed two periods, just before the study groups were established (baseline) and after the study groups had been running for almost a year. For the Gwali study group members, the comparison was done between 2014 (the year before the Gwali study groups were established) and 2015 (the year after the study groups had been in operation for approximately 10 months). For the Golf Course study group members, the comparison was between 2015 (the year before the Golf Course study groups were established) and October 2016 (after the study group had been in operation for 9 months). For Gwali, the pre-participation data were collected by means of members' recall, whereas for Golf Course, there were two surveys (pre- and postassessment). In both the Gwali and Golf Course study groups, the survey amounted to a census 
of all study group members. The total number of respondents interviewed was 118, of whom 99 were from Gwali and 19 from Golf Course.

\subsection{Data analysis}

The qualitative data from both the survey and the participant observation were analysed using thematic analysis, whereby the researcher noted patterns of similarity and differences across participants and groups. This method is recommended by Braun and Clarke (2006) for qualitative research and they declare it as a foundational method in qualitative analysis, hence it was employed in this study as well. The quantitative data from the questionnaires were captured in Microsoft Excel, and thereafter both descriptive and inferential statistics were calculated using Excel and Gretl, the latter being a statistical software package. Descriptive statistics were used in the analysis of personal and household demographic information. Quantified before and after comparisons were made in order to see the differences in production, consumption, sales, as well as in self-assessed knowledge and skill levels. These were also tested for significance using both t-tests for different means and, where possible, the Wilkoxon signed rank test for paired differences.

\section{RESULTS AND DISCUSSION}

\subsection{Demographic information of the study sample}

Demographic characteristics such as gender, age, household size, income, education level and occupation can have significance for people's ability to be agriculturally productive (Muchara, 2011). However, our main purpose in collecting and reporting study group members' demographic characteristics is to convey a sense of who these study group members are.

Table 1: Summary statistics of study group members' demographic characteristics

\begin{tabular}{|c|c|c|c|c|c|}
\hline \multirow{2}{*}{\multicolumn{2}{|c|}{ Variable(s) }} & \multicolumn{2}{|c|}{ Gwali } & \multicolumn{2}{|c|}{ Golf Course } \\
\hline & & \multirow{2}{*}{$\begin{array}{r}\text { Number } \\
3\end{array}$} & \multirow{2}{*}{$\begin{array}{r}\text { Percentage } \\
3 \\
\end{array}$} & \multirow{2}{*}{$\begin{array}{r}\text { Number } \\
0\end{array}$} & \multirow{2}{*}{$\begin{array}{r}\text { Percentage } \\
0\end{array}$} \\
\hline \multirow{6}{*}{ Age (years) } & $20-29$ & & & & \\
\hline & $30-39$ & 7 & 7 & 4 & 21 \\
\hline & $40-49$ & 13 & 13 & 2 & 11 \\
\hline & $50-59$ & 24 & 24 & 9 & 47 \\
\hline & $60+$ & 52 & 53 & 4 & 21 \\
\hline & Total & 99 & 100 & 19 & 100 \\
\hline \multirow{3}{*}{ Gender } & Female & 82 & 83 & 14 & 74 \\
\hline & Male & 17 & 17 & 5 & 26 \\
\hline & Total & 99 & 100 & 19 & 100 \\
\hline \multirow{5}{*}{$\begin{array}{l}\text { Marital } \\
\text { status }\end{array}$} & Single & 29 & 29 & 9 & 47 \\
\hline & Married & 26 & 26 & 5 & 26 \\
\hline & Divorced & 2 & 2 & 1 & 5 \\
\hline & Widowed & 42 & 42 & 4 & 21 \\
\hline & Total & 99 & 100 & 19 & 99 \\
\hline \multirow{2}{*}{$\begin{array}{l}\text { Level of } \\
\text { education }\end{array}$} & Primary & 64 & 65 & 12 & 63 \\
\hline & Secondary & 27 & 27 & 5 & 26 \\
\hline
\end{tabular}




\begin{tabular}{|c|c|c|c|c|c|}
\hline & Tertiary & 2 & 2 & 1 & 5 \\
\hline & No formal & 6 & 6 & 1 & 5 \\
\hline & Total & 99 & 100 & 19 & 99 \\
\hline & Wage employee & 5 & 5 & 4 & 21 \\
\hline Employment & Self-employed & 7 & 7 & 15 & 79 \\
\hline status & Unemployed & 87 & 88 & 0 & 0 \\
\hline & Total & 99 & 100 & 19 & 100 \\
\hline & $\begin{array}{l}\text { Wages from } \\
\text { employment }\end{array}$ & 6 & 6 & 0 & 0 \\
\hline Main & $\begin{array}{l}\text { Earnings from non- } \\
\text { farm business }\end{array}$ & 25 & 25 & 4 & 21 \\
\hline source & Earnings from & 0 & 0 & 0 & 0 \\
\hline & Pensions and grants & 53 & 54 & 4 & 21 \\
\hline & Remittances & 14 & 14 & 0 & 0 \\
\hline & No income & 1 & 1 & 11 & 58 \\
\hline & Total & 99 & 94 & 19 & 100 \\
\hline
\end{tabular}

Source: Field survey, 2015 and 2016

In short, the Gwali study group members are typical of South African rural dwellers, in that they are older, married or widowed, and unemployed, in other words, grant-dependant. In contrast, notwithstanding the small size of Alice, the members of the Golf Course study group appear to have more urban characteristics in that they are somewhat younger, often single, apt to be employed or self-employed. In addition, the preponderance of women in both the Gwali and Golf Course study groups appears to reflect the higher degree of interest among women in home gardens.

\subsection{The impact of study groups on producers' knowledge and skills}

The research sought to measure whether people's knowledge and skills improved due to their involvement in the study groups, based on the self-evaluation of the study group members. In terms of data collection, the situations for Gwali and Golf Course were somewhat different, for reasons explained above. The questionnaire for Gwali included two series of statements regarding knowledge and skills in specific areas (e.g. soil fertility, water harvesting, etc.). The first of these series of statements referred to the year prior to joining the study group (e.g. In 2014 I had a great deal of knowledge about irrigation methods), whereas the second series of statements referred to the same knowledge or skill areas, but at that moment in time (e.g. I have a great deal of knowledge about irrigation methods), effectively meaning after having participated in the study group for the better part of a year.

Tables 2 and 3 summarise the findings for Gwali and Golf Course respectively. In each table, the first column indicates the knowledge/skill area being probed, while the second and third columns display the mean and median self-ratings (where the larger the value, the more strongly respondents agreed that they have knowledge in that area) for both before the study group participation began and after the participation had been well established.

In Table 2, the final two columns report two-sided p-values for the rejection of the null hypothesis of no change in knowledge. The equality of means test is the conventional t-test, in 
this case assuming unequal variances. However, the use of this test for means from Likert-type items is controversial, since the mean itself is not necessarily a meaningful measure of central tendency for Likert-type items, where say the interval between 1 and 2 (strongly disagree and disagree) cannot be compared to that between 4 and 5 (agree and strongly agree) (Carifio \& Perla, 2008). Therefore, an alternative statistical test was also applied, namely the Wilkoxon signed rank test for paired differences, which is a non-parametric test which rather assumes that the median is the measure of central tendency.

In the Gwali study group, for members across all the knowledge and skill areas, the null hypothesis of no change is rejected at an extremely low significance level, whether using the parametric or non-parametric test. At least in their own views, study group participants judge that their knowledge and skills in relation to vegetable production in 2015 were greater than in 2014 before the study groups were introduced.

Table 2: Before and after comparisons of knowledge and skills based on self-assessment, Gwali study groups

\begin{tabular}{|l|c|c|c|c|}
\hline Knowledge and skill areas & $\begin{array}{c}\text { Mean/ } \\
\text { median } \\
\text { 'before' } \\
\text { (2014) }\end{array}$ & $\begin{array}{c}\text { Mean/ } \\
\text { median } \\
\text { 'after' } \\
\text { (2015) }\end{array}$ & $\begin{array}{c}\text { Equality } \\
\text { of means } \\
\text { test p- } \\
\text { value }\end{array}$ & $\begin{array}{c}\text { Wilkoxon } \\
\text { signed } \\
\text { rank test } \\
\text { p-value }\end{array}$ \\
\hline $\begin{array}{l}\text { I had/have a great deal of knowledge about } \\
\text { irrigation methods. }\end{array}$ & $1.48 / 1.0$ & $\begin{array}{c}2.86 / \\
3.0\end{array}$ & $1.54 \mathrm{e}-30$ & $2.92 \mathrm{e}-17$ \\
\hline $\begin{array}{l}\text { I had/have a great deal of knowledge about soil } \\
\text { fertility. }\end{array}$ & $1.39 / 1.0$ & $\begin{array}{c}2.75 / \\
3.0\end{array}$ & $3.38 \mathrm{e}-29$ & $1.30 \mathrm{e}-17$ \\
\hline $\begin{array}{l}\text { I had/have a great deal of skill on how to tell } \\
\text { how fertile the soil is. }\end{array}$ & $1.36 / 1.0$ & $\begin{array}{c}2.70 / \\
3.0\end{array}$ & $2.65 \mathrm{e}-30$ & $7.45 \mathrm{e}-19$ \\
\hline $\begin{array}{l}\text { I had/have a great deal of knowledge and skills } \\
\text { on how to maintain the fertility of the soil. }\end{array}$ & $1.41 / 1.0$ & $\begin{array}{c}2.73 / \\
3.0\end{array}$ & $4.20 \mathrm{e}-28$ & $3.97 \mathrm{e}-18$ \\
\hline $\begin{array}{l}\text { I had/have a great deal of knowledge and skills } \\
\text { about fertiliser applications. }\end{array}$ & $1.33 / 1.0$ & $\begin{array}{c}2.68 / \\
3.0\end{array}$ & $7.56 \mathrm{e}-30$ & $1.76 \mathrm{e}-17$ \\
\hline $\begin{array}{l}\text { I had/have a great deal of knowledge and skills } \\
\text { on how to control pests in crops. }\end{array}$ & $1.38 / 1.0$ & $\begin{array}{c}2.72 / \\
3.0\end{array}$ & $1.34 \mathrm{e}-26$ & $2.13 \mathrm{e}-17$ \\
\hline $\begin{array}{l}\text { I had/have a great deal of knowledge about } \\
\text { pesticides. }\end{array}$ & $1.46 / 1.0$ & $\begin{array}{c}2.70 / \\
3.0\end{array}$ & $5.13 \mathrm{e}-20$ & $5.97 \mathrm{e}-16$ \\
\hline $\begin{array}{l}\text { I had/have a great deal of knowledge about } \\
\text { timing of planting. }\end{array}$ & $1.44 / 1.0$ & $\begin{array}{c}2.80 / \\
3.0\end{array}$ & $1.76 \mathrm{e}-26$ & $3.48 \mathrm{e}-18$ \\
\hline $\begin{array}{l}\text { I had/have a great deal of knowledge about } \\
\text { different techniques of rainwater harvesting. }\end{array}$ & $1.43 / 1.0$ & $\begin{array}{c}3.45 / \\
4.0\end{array}$ & $3.19 \mathrm{e}-54$ & $3.16 \mathrm{e}-18$ \\
\hline $\begin{array}{l}\text { I had/have a great deal of knowledge about } \\
\text { drought resistant crops. }\end{array}$ & $1.42 / 1.0$ & $\begin{array}{c}2.69 / \\
3.0\end{array}$ & $1.10 \mathrm{e}-28$ & $1.47 \mathrm{e}-18$ \\
\hline $\begin{array}{l}\text { I had/have a great deal of knowledge and skills } \\
\text { on how to plough and plant. }\end{array}$ & $1.91 / 2.0$ & $\begin{array}{c}3.54 / \\
4.0\end{array}$ & $9.13 \mathrm{e}-45$ & $2.65 \mathrm{e}-16$ \\
\hline $\begin{array}{l}\text { I placed/place great importance in learning } \\
\text { new skills and knowledge. }\end{array}$ & $1.92 / 2.0$ & $\begin{array}{c}3.42 / \\
3.0\end{array}$ & $8.52 \mathrm{e}-40$ & $9.52 \mathrm{e}-18$ \\
\hline
\end{tabular}

Note: $\mathrm{n}=99$, except for Wilkoxon tests where the effective sample sizes change because 'ties' are disregarded from the calculation of the relevant test statistics; all tests are significant at well below the $1 \%$ level.

Source: Field survey, 2015 
For Golf Course, the Wilcoxon test was not feasible, because the small sample size was such that the median did not change from before to after for any of the knowledge/skill areas. Therefore, only the results of the equality of means test are shown (Table 3). There was a significantly positive change from before to after for eight of the 12 knowledge/skills areas at the $5 \%$ significance level or lower. It should be mentioned, however, that the mean increased for all the knowledge/skill areas, whether or not the t-test yielded a significant result. One could argue that, strictly speaking, the statistical tests are redundant, since we are not inferring from a sample to a population, rather we are analysing data from all the study group members in the study group initiative. Be that as it may, the Golf Course results are consistent with those from Gwali, albeit not as strong.

Table 3: Before and after comparisons of knowledge and skills based on self- assessment, Golf Course study group

\begin{tabular}{|l|c|c|c|}
\hline Knowledge and skill areas & $\begin{array}{c}\text { Mean/ } \\
\text { median } \\
\text { 'before' } \\
\text { (2015) }\end{array}$ & $\begin{array}{c}\text { Mean/ } \\
\text { median } \\
\text { ('after') } \\
\mathbf{2 0 1 6}\end{array}$ & $\begin{array}{c}\text { Equality } \\
\text { of means } \\
\text { test p- } \\
\text { value }\end{array}$ \\
\hline $\begin{array}{l}\text { I had/have a great deal of knowledge about irrigation } \\
\text { methods. }\end{array}$ & $1.89 / 2.0$ & $2.26 / 2.0$ & $0.017 * *$ \\
\hline I had/have a great deal of knowledge about soil fertility. & $1.53 / 2.0$ & $2.05 / 2.0$ & 0.333 \\
\hline $\begin{array}{l}\text { I had/have a great deal of skill on how to tell how fertile } \\
\text { the soil is. }\end{array}$ & $1.63 / 2.0$ & $2.03 / 2.0$ & 1.000 \\
\hline $\begin{array}{l}\text { I had/have a great deal of knowledge and skills on how to } \\
\text { maintain the fertility of the soil. }\end{array}$ & $2.00 / 2.0$ & $2.01 / 2.0$ & $0.005 * * *$ \\
\hline $\begin{array}{l}\text { I had/have a great deal of knowledge and skills about } \\
\text { fertiliser applications. }\end{array}$ & $1.95 / 2.0$ & $2.42 / 2.0$ & 0.623 \\
\hline $\begin{array}{l}\text { I had/have a great deal of knowledge and skills on how to } \\
\text { control pests in crops. }\end{array}$ & $1.53 / 2.0$ & $2.37 / 2.0$ & 0.188 \\
\hline I had/have a great deal of knowledge about pesticides. & $1.37 / 2.0$ & $2.02 / 2.0$ & $0.022 * *$ \\
\hline $\begin{array}{l}\text { I had/have a great deal of knowledge about timing of } \\
\text { planting. }\end{array}$ & $1.21 / 2.0$ & $2.95 / 2.0$ & $0.038 * *$ \\
\hline $\begin{array}{l}\text { I had/have a great deal of knowledge about different } \\
\text { techniques of rainwater harvesting. }\end{array}$ & $1.42 / 2.0$ & $2.38 / 2.0$ & $\begin{array}{l}3.25 \mathrm{e}- \\
005 * *\end{array}$ \\
\hline $\begin{array}{l}\text { I had/have a great deal of knowledge about drought } \\
\text { resistant crops. }\end{array}$ & $1.37 / 2.0$ & $2.79 / 2.0$ & $0.199 * *$ \\
\hline $\begin{array}{l}\text { I had/have a great deal of knowledge and skills on how to } \\
\text { plough and plant. }\end{array}$ & $1.79 / 2.0$ & $2.26 / 2.0$ & $\begin{array}{c}1.82 \mathrm{e}- \\
00 * * *\end{array}$ \\
\hline $\begin{array}{l}\text { I placed/place great importance in learning new skills and } \\
\text { knowledge. }\end{array}$ & $1.11 / 2.0$ & $2.63 / 2.0$ & $\begin{array}{c}1.17 \mathrm{e}- \\
005 * * *\end{array}$ \\
\hline
\end{tabular}

Note: $\mathrm{n}=19$, any $\mathrm{p}$-value less than 0.10 can be regarded as statistically significant, however the lower the $\mathrm{p}$-value the greater the degree of statistical significance.

Source: Field survey, 2016

How much can one 'trust' people's self-evaluation regarding their knowledge? That is a fair and difficult question. It is important to note, however, that FFS are based on the principle of constructivism, meaning participants construct their own meaning from their own (somewhat 
S. Afr. J. Agric. Ext.

Vol. 47 No. 3, 2019: $70-82$

http://dx.doi.org/10.17159/2413-3221/2019/v47n3a516
Apleni, Aliber,

Zhou \& Zantsi

(License: CC BY 4.0)

shared) experience (Duveskog, 2013). Self-assessment is fully in keeping with this constructivist ethos.

With this in mind, one thing that is particularly interesting about the findings reported in Tables 2 and 3 is the last statement, which in fact is not about a specific knowledge or skill area, but rather about people's perceptions about the importance of learning. Study group participants do not just feel that they have more knowledge and skills than they had before, they have more appreciation of the importance of developing their knowledge and skills.

\subsection{Production, consumption and sales}

This section presents the before and after comparisons of production, consumption and sales of vegetables. The comparison of production levels before and after the existence of study groups is shown in Tables 4 and 5 for Gwali and Golf Course respectively.

For both sites, there was an increase in the average production of all planted crops, as shown by the percentage changes, and for almost all of these the change was statistically significant. For Gwali, the production of tomatoes and beetroot recorded the highest percentage increments, while lettuce and potatoes increased the least. For Golf Course, the highest percentage increases were for dry beans and pumpkin, and the lowest for spinach and lettuce. What neither table shows is that at both Gwali and Golf Course, average production of maize declined somewhat, presumably because producers were choosing to reallocate space to other crops.

Table 4: Before and after comparisons of production key garden crops for Gwali

\begin{tabular}{|l|r|r|r|r|}
\hline Vegetable & Average 2014 & Average 2015 & \% change & \multicolumn{1}{c|}{ p-value } \\
\hline Cabbage (head) & 4.29 & 6.20 & $44.5 \%$ & $9.9 \mathrm{e}-4$ \\
\hline Spinach $(\mathrm{kg})$ & 4.91 & 6.56 & $33.6 \%$ & 0.011 \\
\hline Potatoes $(\mathrm{bags})$ & 7.76 & 9.69 & $24.9 \%$ & 0.039 \\
\hline Carrots $(\mathrm{kg})$ & 1.90 & 2.83 & $48.9 \%$ & 0.029 \\
\hline Lettuce $(\mathrm{head})$ & 1.66 & 2.14 & $28.9 \%$ & 0.193 \\
\hline $\begin{array}{l}\text { Dry beans } \\
\text { (bags) }\end{array}$ & 3.58 & 4.93 & $37.7 \%$ & 0.002 \\
\hline Beetroot $(\mathrm{kg})$ & 2.22 & 5.27 & $137.4 \%$ & $9.6 \mathrm{e}-14$ \\
\hline Onion $(\mathrm{kg})$ & 2.70 & 4.14 & $53.3 \%$ & $4.7 \mathrm{e}-5$ \\
\hline Pumpkin $(\mathrm{kg})$ & 1.67 & 3.28 & $96.4 \%$ & 0.001 \\
\hline Tomatoes $(\mathrm{kg})$ & 0.59 & 2.94 & $398.3 \%$ & $2.2 \mathrm{e}-10$ \\
\hline
\end{tabular}

Note: $\mathrm{n}=99$; any $\mathrm{p}$-value less than 0.10 can be regarded as statistically significant, however, the lower the $\mathrm{p}$ value, the greater the degree of statistical significance.

Source: Field survey, 2015

Table 5: Before and after comparisons of production key garden crops for Golf Course

\begin{tabular}{|l|r|r|r|r|}
\hline Vegetable & Average 2015 & Average 2016 & \% change & \multicolumn{1}{c|}{ p-value } \\
\hline Cabbage (head) & 1.68 & 6.11 & $263 \%$ & 0.0009 \\
\hline Spinach $(\mathrm{kg})$ & 4.26 & 8.79 & $106 \%$ & 0.0001 \\
\hline Potatoes $(\mathrm{kg})$ & 1.63 & 10.05 & $516 \%$ & $9.85 \mathrm{e}-006$ \\
\hline Carrots $(\mathrm{kg})$ & 1.00 & 6.00 & $500 \%$ & $1.59 \mathrm{e}-005$ \\
\hline
\end{tabular}




\begin{tabular}{|l|r|r|r|r|}
\hline Lettuce (head) & 1.05 & 1.74 & $65 \%$ & 0.032 \\
\hline Dry beans $(\mathrm{kg})$ & 0.05 & 3.79 & $7100 \%$ & $3.90 \mathrm{e}-006$ \\
\hline Beetroot $(\mathrm{kg})$ & 1.00 & 5.58 & $458 \%$ & $4.05 \mathrm{e}-006$ \\
\hline Onion $(\mathrm{kg})$ & 1.74 & 5.53 & $218 \%$ & 0.0001 \\
\hline Pumpkin $(\mathrm{kg})$ & 0.05 & 0.95 & $1700 \%$ & 0.056 \\
\hline Tomatoes $(\mathrm{kg})$ & 0.00 & 0.79 & Undefined & 0.069 \\
\hline
\end{tabular}

Note: $\mathrm{n}=19$; any $\mathrm{p}$-value less than 0.10 can be regarded as statistically significant, however, the lower the pvalue, the greater the degree of statistical significance.

Source: Field survey, 2016

Based on local food retail prices in 2017, it was estimated that the average value of production per member for Gwali increased from R1435 to R2450, while for Golf Course the increase was from R140 to R670.

In addition to production levels, respondents were asked how much produce was consumed by the household, how much was sold, how much was fed to livestock, and how much was donated to others. Tables 6 and 7 summarise the before and after comparisons regarding consumption and sales for Gwali and Golf Course respectively.

The results for Gwali are somewhat surprising in that for a number of vegetable crops, an increase in sales was greater than that of production, meaning that consumption actually declined. When the University of Fort Hare and the Nkonkobe Farmers' Association initiated the study groups, the general assumption was that these were food deficit households for which additional production would mainly translate into additional consumption. The implementers of the initiative had not anticipated that participants were so keen to sell, but the qualitative findings also revealed that at least some members were interested in production for the market from the beginning. Our interpretation is that the larger amount of vegetable production across the board compensated for those vegetables of which the households chose to consume less in favour of selling.

Table 6: Before and after comparisons of consumption and sales of key garden crops, Gwali

\begin{tabular}{|l|r|r|r|r|r|r|r|r|}
\hline \multirow{2}{*}{ Vegetable } & \multicolumn{3}{|c|}{ Garden produce consumed } & \multicolumn{3}{c|}{ Garden produce sold } \\
\cline { 2 - 9 } & $\begin{array}{c}\text { Average } \\
\mathbf{2 0 1 4}\end{array}$ & $\begin{array}{c}\text { Average } \\
\mathbf{2 0 1 5}\end{array}$ & $\begin{array}{c}\text { \% } \\
\text { change }\end{array}$ & p-value & $\begin{array}{c}\text { Average } \\
\mathbf{2 0 1 4}\end{array}$ & $\begin{array}{c}\text { Average } \\
\mathbf{2 0 1 5}\end{array}$ & $\begin{array}{c}\text { \% } \\
\text { change }\end{array}$ & p-value \\
\hline Cabbage (head) & 3.3 & 3.4 & $3 \%$ & 0.734 & 0.9 & 2.6 & $195 \%$ & $9.9 \mathrm{e}-6$ \\
\hline Spinach $(\mathrm{kg})$ & 4.2 & 3.4 & $-19 \%$ & 0.058 & 0.6 & 3.1 & $433 \%$ & $2.1 \mathrm{e}-7$ \\
\hline Potatoes $(\mathrm{bags})$ & 5.3 & 4.8 & $-8 \%$ & 0.302 & 2.5 & 4.6 & $89 \%$ & 0.009 \\
\hline Carrots $(\mathrm{kg})$ & 1.6 & 1.6 & $2 \%$ & 0.919 & 0.3 & 1.1 & $224 \%$ & $3.6 \mathrm{e}-4$ \\
\hline Lettuce $(\mathrm{head})$ & 1.3 & 1.2 & $-5 \%$ & 0.800 & 0.4 & 0.9 & $144 \%$ & 0.009 \\
\hline Dry beans $(\mathrm{bags})$ & 2.9 & 3.8 & $28 \%$ & 0.011 & 0.6 & 1.1 & $80 \%$ & 0.044 \\
\hline Beetroot $(\mathrm{kg})$ & 1.7 & 3.8 & $127 \%$ & $2.0 \mathrm{e}-12$ & 0.5 & 1.4 & $173 \%$ & $1.8 \mathrm{e}-4$ \\
\hline Onion $(\mathrm{kg})$ & 2.3 & 2.4 & $6 \%$ & 0.542 & 0.4 & 1.7 & $338 \%$ & $6.7 \mathrm{e}-8$ \\
\hline Pumpkin $(\mathrm{kg})$ & 1.0 & 1.9 & $89 \%$ & 0.001 & 0.4 & 1.3 & $257 \%$ & $1.4 \mathrm{e}-4$ \\
\hline Tomatoes $(\mathrm{kg})$ & 0.5 & 1.9 & $255 \%$ & $3.1 \mathrm{e}-8$ & 0.1 & 1.0 & $1600 \%$ & $4.9 \mathrm{e}-7$ \\
\hline
\end{tabular}

Notes: $\mathrm{n}=99$; any $\mathrm{p}$-value less than 0.10 can be regarded as statistically significant, however, the lower the $\mathrm{p}$ value, the greater the degree of statistical significance 
Source: Field survey, 2016

For Golf Course, there was an increase in averages of garden produce consumed for 2016 as compared to 2015 where the consumption of most vegetables doubled. Regarding sales, it must be noted that the volumes were very small. What is significant however is that in 2015 , only one respondent sold one vegetable (spinach), whereas in 2016, eight of the 19 members sold one or more vegetables.

Table 7: Before and after comparisons of consumption and sales of key garden crops, Golf Course

\begin{tabular}{|c|c|c|c|c|c|c|c|c|}
\hline \multirow{2}{*}{ Vegetable } & \multicolumn{4}{|c|}{ Garden produce consumed } & \multicolumn{4}{|c|}{ Garden produce sold } \\
\hline & \begin{tabular}{|c|} 
Average \\
2015 \\
\end{tabular} & $\begin{array}{c}\text { Average } \\
2016\end{array}$ & $\begin{array}{c}\% \\
\text { change }\end{array}$ & p-value & \begin{tabular}{|c|} 
Average \\
2015 \\
\end{tabular} & \begin{tabular}{|c|} 
Average \\
2016 \\
\end{tabular} & \% change & p-value \\
\hline $\begin{array}{l}\text { Cabbage } \\
\text { (head) }\end{array}$ & 1.37 & 4.58 & $235 \%$ & 0.0006 & 0.00 & 1.00 & Undefined & 0.0948 \\
\hline \begin{tabular}{|l|}
$\begin{array}{l}\text { Spinach } \\
(\mathrm{kg})\end{array}$ \\
\end{tabular} & 3.32 & 7.16 & $116 \%$ & $\begin{array}{r}2.06 \mathrm{e}- \\
006\end{array}$ & 0.16 & 1.16 & $633 \%$ & 0.1535 \\
\hline \begin{tabular}{|l} 
Potatoes \\
$(\mathrm{kg})$
\end{tabular} & 1.63 & 9.00 & $452 \%$ & $\begin{array}{r}2.62 \mathrm{e}- \\
005 \\
\end{array}$ & 0.00 & 1.05 & Undefined & 0.2146 \\
\hline $\begin{array}{l}\text { Carrots } \\
(\mathrm{kg})\end{array}$ & 0.89 & 5.16 & $476 \%$ & $\begin{array}{r}9.63- \\
007\end{array}$ & 0.00 & 0.74 & Undefined & 0.1673 \\
\hline \begin{tabular}{|l|}
$\begin{array}{l}\text { Lettuce } \\
\text { (head) }\end{array}$ \\
\end{tabular} & 0.79 & 1.47 & $87 \%$ & 0.2746 & 0.00 & 0.26 & Undefined & 0.3306 \\
\hline $\begin{array}{l}\text { Dry beans } \\
(\mathrm{kg})\end{array}$ & 0.05 & 3.26 & $6100 \%$ & $\begin{array}{r}7.99 \mathrm{e}- \\
006\end{array}$ & 0.00 & 0.26 & Undefined & 0.3306 \\
\hline $\begin{array}{l}\text { Beetroot } \\
(\mathrm{kg})\end{array}$ & 0.84 & 4.89 & $4.81 \%$ & $\begin{array}{r}9.36 \mathrm{e}- \\
006 \\
\end{array}$ & 0.00 & 0.42 & Undefined & 0.3306 \\
\hline Onion $(\mathrm{kg})$ & 1.47 & 5.21 & $254 \%$ & $\begin{array}{r}1.03 \mathrm{e}- \\
005\end{array}$ & 0.00 & 0.32 & Undefined & 0.3306 \\
\hline $\begin{array}{l}\text { Pumpkin } \\
(\mathrm{kg})\end{array}$ & 0.05 & 0.95 & $1700 \%$ & 0.0597 & 0.00 & 0.00 & Undefined & NA \\
\hline $\begin{array}{l}\text { Tomatoes } \\
(\mathrm{kg})\end{array}$ & 0.00 & 0.79 & $\begin{array}{r}\text { Undefin } \\
\text { ed }\end{array}$ & 0.0694 & 0.00 & 0.00 & Undefined & NA \\
\hline
\end{tabular}

Note: $\mathrm{n}=19$; any $\mathrm{p}$-value less than 0.10 can be regarded as statistically significant, however, the lower the $\mathrm{p}$ value, the greater the degree of statistical significance.

Source: Field survey, 2016

Overall, the results suggest an impressive increase in vegetable production and consumption, and to some extent in sales, coinciding with the introduction of the study groups.

\section{CONCLUSION AND RECOMMENDATIONS}

This study sought to contribute to the thin body of literature concerning the impact of the FFS approach in the South African context. The main focus was to determine whether the introduction of FFS-style study groups could be associated with a change in knowledge and production. Based on the results for both the Gwali and Golf Course study group members, it can be concluded that participation in study groups does indeed coincide with an increase in self-assessed knowledge and in production, and furthermore, in increases in both vegetable 
consumption and cash income. It is not a great leap to suppose that the relationship between the introduction of the study groups and the changes in knowledge and production is a causal one. Given the fact that, over time, rural households in the Eastern Cape Province have left their arable fields fallow in favour of garden production (Connor \& Mtwana, 2017; De La Hey $\&$ Beinart, 2016), the experience with the Gwali and Golf Course study groups is potentially very important.

The recommendation following from the above is that further experimentation with farmer field schools and FFS-inspired approaches should be supported, not least by the provincial agriculture departments. Such further experimentation could be focused on home gardening, as with the study groups described in this article. In the medium term, this could assist in reinvigorating government's direct support for household-level food security. However, the approach could also be tried in the context of other production systems, for instance, field crop production and livestock production. These may prove more challenging, depending on local circumstances, as a key practical aspect of the study group approach is the ease with which study group members are able to convene on a frequent basis, which generally seems to mean residing within the same village. If, for instance, field crop farmers are few and far between, as they appear to be across much of the Eastern Cape Province, then constituting a function study group might prove difficult. However, this is why experimenting with the approach is critical, because while the potential of the approach appears to be great, its limitations must also be understood.

Even within the context of relatively straightforward home gardening study groups, there remains much that we do not understand, most obviously, what accounts for the impressive results noted above. Is it higher yields due to improved production methods, which in turn is due to members' improved knowledge? Are households using a greater share of their garden space? And how important is new knowledge or skill, relative to the heightened motivation that seems to come with participation in a sociable study group? Furthermore, as for the improved knowledge and skills, is this a function of the constructivist method itself, or rather due to the frequency of interactions, whether with the facilitator or the other study group members? It could be either, or both.

One concerning piece of evidence from other research based in the Eastern Cape Province is that, of the modest share of small-scale producers who do receive attention from government extension officers, most have only one or two interactions with these officers within a 12month period (Aliber et al, 2017; Raymond Mhlaba Farmers' Association, 2018). In contrast, participants in the Gwali and Golf Course study groups typically engage with their facilitators and groups no less than 20 times. Moreover, there is indirect evidence that the constructivist approach used in the study groups is also effective, for instance the current finding that after participation in the study groups, members indicated a greater appreciation for the value of learning. Nevertheless, further research is critical so that we know with greater certainty.

\section{ACKNOWLEDGEMENTS}

The financial assistance of the Agricultural and Rural Development Research Institute (ARDRI) and the Risk and Vulnerability Science Centre (RVSC) towards this research is hereby acknowledged. Opinions expressed and conclusions arrived at are those of the authors and are not necessarily to be attributed to ARDRI and RVSC. 


\section{REFERENCES}

ALIBER, M. \& HART, T.G.B., 2009. Should subsistence farming be supported as a strategy to address rural food insecurity? Agrekon, 48(4):434-458.

ALIBER, M., GWALA, L., YUSUF, F., RAHIM, A., MUSHUNJE, A., ARWARI, M., MAKHUNGA, Z. \& SHILIGA, Z., 2017. Government and small-scale agriculture: Understanding the successes and failures in respect of learning, planning and implementation. Available from: http://psppdknowledgerepository.org/component/jdownloads/download/287government-and-small-scale-agriculture-understanding-the-successes-and-failures-inrespect-of-learning-planning-and-implementation

BRAUN, V. \& CLARKE, V., 2006. Using thematic analysis in psychology. Qual. Res. Psychol., 3(2):77-101.

BRAUN, A., JIGGINS, J., RÖLING, N., VAN DEN BERG, H. \& SNIJDERS, P., 2006. A global survey and review of farmer field school experiences. Available from: https://www.researchgate.net/profile/J_Jiggins/publication/228343459_A_Global_Surv ey_and_Review_of_Farmer_Field_School_Experiences/links/0046353bd1e61ab7f7000 000/A-Global-Survey-and-Review-of-Farmer-Field-School-Experiences.pdf

CARIFIO, L. \& PERLA, R., 2008. Resolving the 50-year debate around using and misusing Likert scales. Med. Educ., 2(12):1150-1152.

CONNOR, T. \& MTWANA, N., 2017. Vestige garden production and deagrarianization in three villages in the Eastern Cape, South Africa. S. Afr. Geogr. J., 100(1):82-103.

DAVIS, K., 2006. Farmer field schools: A boom or bust for extension in Africa. J. Agric. Educ. Ext., 13(1):91-97.

DAVIS, K., NKONYA, E., MEKONNEN, D.A., ODENDO, M., MIIRO, R. \& NKUBA, J., 2010. Impact of farmer field schools on agricultural productivity and poverty in East Africa. IFPRI Discussion Paper 00992. Washington, D.C., United States of America.

DE LA HEY, M. \& BEINART, W., 2016. Why have South African smallholders largely abandoned arable production in fields? A case study. J. South. Afr. Stud., 43(4):753-770.

DEPARTMENT OF AGRICULTURE, FORESTRY AND FISHERIES (DAFF), 2013. Strategic plan for smallholder support 2011-2014/15. Available from: webapps.daff.gov.za/SmallHolderDevelopment/SMREPORTS/eLibrary/Strategic\%20P lan\%20for\%20Smallholder\%20Support.pdf

DEPARTMENT OF AGRICULTURE, FORESTRY AND FISHERIES (DAFF), 2014. Draft national policy on extension and advisory services. Available from: https://www.daff.gov.za/doaDev/topMenu/National\%20Policy.pdf

DUVESKOG, D., 2013. Farmer field schools as a transformative learning space in the rural African setting. PhD Thesis, Swedish University of Agricultural Sciences.

FRIIS-HANSEN, E. \& DUVESKOG, D., 2012. The empowerment rout to well-being: An analysis of farmer field schools in East Africa. World Dev., 40(2):414-427.

KOCH, B.H. \& TERBLANCHE, S.E., 2013. An overview of agricultural extension in South Africa. S. Afr. J. Agric. Ext., 41(1):107-117. 
LUKHALO, T., 2017. An expenditure review of agricultural extension system in South Africa. Masters Thesis, University of Pretoria.

MUCHARA, B., 2011. Analysis of food value chains in smallholder crop and livestock enterprises in the Eastern Cape Province of South Africa. Masters Thesis, University of Fort Hare.

NATIONAL PLANNING COMMISSION, 2011. The national development plan 2030: Our future - make it work. Available from: https://www.gov.za/sites/default/files/gcis_document/201409/ndp-2030-our-futuremake-it-workr.pdf

PIENAAR, L. \& VON FINTEL, D., 2014. Hunger in the former apartheid homelands: Determinants of convergence on a century after the 1913 land act. Agrekon, 53(4):38-67.

PONTIUS, J., DILTS, R. \& BARTTLET, A., 2002. From farmer field school to community IPM: Ten years of IPM training in Asia. Bangkok: Food and Agriculture Organization.

RAYMOND MHLABA FARMERS' ASSOCIATION, 2018. Results of the first annual farmer satisfaction survey for Raymond Mhlaba Local Municipality. Available from: http://rmfa.org.za/constitution-policy

STATISTICS SOUTH AFRICA (StatsSA), 2012. Census 2011. Available from: http://www.statssa.gov.za/?page_id=3839

STATISTICS SOUTH AFRICA (StatsSA), 2016. General household survey. Available from: www.statssa.gov.za/?p=9922

WORTH, S.H., 2008. An assessment of the appropriateness of agricultural extension education in South Africa. PhD Thesis, University of KwaZulu-Natal. 
